Universal Decimal Classification (UDC) 614.7: 616.1/-09-084

\title{
VIOLATION OF HOMEOSTASIS OF THE MAIN TYPES OF EXCHANGE AND IMMUNE RESISTANCE STATUS IN CHILDREN WITH SUBCLINICAL HYPOVITAMINOSIS IN CONDITIONS OF EXPOSURE TO CHEMICAL ENVIRONMENTAL FACTORS
}

\author{
A.M. Yambulatov ${ }^{2}$, O.U. Ustinova ${ }^{1,3}$, K.P. Luzhetskiy ${ }^{1,3}$ \\ ${ }^{1}$ FBSI "Federal Scientific Center for Medical and Preventive Health Risk Management Technologies" of \\ Rospotrebnadzor, 82, Monastyrskaya st., Perm, 614045, Russian Federation \\ ${ }^{2}$ Federal Service for Supervision of Consumer Rights Protection and Human Welfare in the Perm region, \\ 50, Kuibysheva st., Perm, 614016, Russian Federation \\ ${ }^{3}$ FSBEI HPE «Perm State National Research University", 15, Bukireva st., Perm, 614990, Russian \\ Federation
}

The study of the chemical substances' content of anthropogenic origin in children with subclinical polyhypovitaminosis was conducted. It was found that a deficiency of vitamins A, C, E, B6 and B12 increases the risk of developing of elevated concentrations of organic substances of technogenic origin in blood in 1.4-6.9 times. In children with subclinical polyhypovitaminosis and high blood phenol, formaldehyde, aromatic hydrocarbons, and organ chlorine compounds increases the tension of erythropoiesis, decreases the activity of proliferating processes of lympfomonocytic germ cell factors of nonspecific resistance. Even subclinical forms of polyhypovitaminosis on the background of high content of organic compounds in the blood of children are accompanied by a slowdown of protein and carbohydrate metabolism, depletion of antioxidant defense system of reserves and shortage of energy metabolism. Developing disorders of fat metabolism in children with subclinical polyhypovitaminosis occur against a background of strained reactions of hormonal regulation that, in case of the progressive course may pose a threat to the early development of cardiovascular disease in older age groups.

Key words: children, subclinical polyhypovitaminosis, chemicals, man-made origin, metabolism, immunoresistance.

If we overview numerous researches dedicated to vitamins provision of the Russian Federation population we can see that subclinical polyhypovitaminosis is widely spread in children $[1,5,7$, 11]. According to the data given by Russian Academy of Science Institute of Nutrition, up to $70 \%$ of children in the RF regardless of age, season or place of residence have combined deficiency of 3 and more vitamins. [13]. In particular, 60-90\% of examined children have $B$ group vitamin deficiency (thiamine, riboflavin, pyridoxine, nicotinic acid and folic acid), more than $40 \%$ have beta-carotene deficiency, and $70-90 \%$ suffer from vitamin $C$ deficiency $[11,12,14]$. Vitamin deficiency results in children health impairment, poorer mental and physical performance, disorders in detoxification processes of foreign substances, physical and mental retardation, immune insufficiency, susceptibility to various pathologies evolvement and chronic diseases [1, $6,8,10]$.

Majority of researchers consider food vitamin insufficiency (improper nutrition and natural low vitamin content in food stuffs) to be the primary reason for polyhypovitaminosis evolvement $[1$, $2,5]$. At the same time we should note that negative effects causes by production induced chemicals can also exert significant influence on children vitamin provision $[1,3,4,11]$. L.A. Chesnokova at al (2013) detected total A, E, C, B, $\mathrm{B}_{2}$ and $\mathrm{B}_{6}$ vitamin deficiency in children living in Eastern territory economic zone of Orenburg region and explained its evolvement by environment (air, soil and drinking water) pollution with production induced chemical substances. Those substances enhanced free-radical oxidation processes that determined greater vitamin consumption [14]. According to V.G.Rebrov at al (2008) retinol and its 
ethers, riboflavin, pyridoxine hydrochloride, pantothenic and ascorbic acids and their salts, folic acid, colecalciferol, argocalciferol and rutin are the most sensitive to negative influence of production induced chemicals [12]. Yu.G. Kovalsky at al (2002) proved that children chronically exposed to methanthiol had lower content of $\mathrm{A}, \mathrm{C}$, and $\mathrm{E}$ vitamins in their blood [7]. N.A,Kuzmichiova received similar data when examining children living in areas where air was polluted by chemicals with strong oxidants properties $[6,7,9]$.

The primary goal of our research was to study mechanisms of metabolism disorders evolvement in children suffering from subclinical hypovitaminosis and affected by environmental chemical factors.

We needed to receive objective estimation of the influence that is exerted by vitamin provision on primary metabolism processes in children being affected by complex combined effect of production induced environmental chemical factors. Therefore we conducted profound laboratory examination of 108 children aged 5-6 years and attending a preschool educational establishment for not less than 3 years. All preschool educational establishments were situated in a big industrial city. Relying on the results of preliminary medical and social questioning we excluded the following children from our examination pool: children from asocial families; children from families with incomes lower than living wage; children suffering from severe chronic diseases; as well as children with heritable and congenital pathologies.

We used a set of sanitary and hygienic, laboratory and mathematic techniques in our research. Medical and biological research was conducted in full conformity with the ethic principles stated in Helsinki Declaration (1975; expanded 1983) and the Russian Federation State Standard "Appropriate Clinical Practice" ГОСТ-P 523792005 (ICH E6 GCP).

To estimate air quality in preschool educational establishments we took air samples in game rooms and carried out chemical analysis to detect phenol, formaldehyde, ethyl benzene and benzene content. Samples were taken in accordance with the R ISO 16000-1-2007 State Standard "Air in closed premises. Part 1. Sampling. General guidelines." We defined formaldehyde with the use of highly effective liquid chromatography in accordance with Control Guidelines No. 4.1.1045-01 "Defining formaldehyde and maximum permissible aldehydes $\left(\mathrm{C}_{2}-\mathrm{C}_{10}\right)$ in air with highly effective liquid chromatography". Benzene and ethyl benzene were defined with the use of gas chromatography; phenol with the use of spectrophotometric techniques according to "Air pollution control manual 52.04.186-89" item 5.3.5.1 and item 5.3.3.5.

All examinations of air samples were conducted with the use of up-to-date analytical equipment. Thus, phenol content was defined with «Lambda» spectrophotometer produced by «PerkinElmer» Inc., USA; benzene and ethyl benzene content was analyzed with "Kristall 5000" gas chromatograph equipped with HP-FFAP $50 * 0.32 * 0.50$ capillary column and ionization-inflame detector. We measured formaldehyde concentration with «Agilent 1200 Series» liquid chromatograph equipped with diode-matrix detector. Daily average concentrations of chemical substances in the air of the examined preschool educational establishments were calculated as arithmetical mean value of their single concentration in samples taken during 24 hours.

Water quality estimation in preschool educational establishments was carried out on the basis of monitoring research conducted by Federal Information Fund for Sanitary and Hygienic Monitoring and in-situ research results. We defined chloroform and carbon tetrachloride with the use of "Khromatek-Kristall 5000" gas chromatograph equipped with halogen selective detector.

We determined formaldehyde, phenol, ethyl benzene, benzene, chloroform and carbon tetrachloride content in children's blood according to standard techniques.

We conducted micro-biological tests combined with colorimetric technique («ID-Vit ${ }^{\circledR}$ Vitamin $B_{6} »$ and «ID-Vit ${ }^{\circledR}$ Vitamin $B_{12} »$, Immunodiagnostik AG, Germany) to define $B_{6}$ and $B_{12}$ vitamins content in blood. $\mathrm{C}$ vitamin content was determined by colorimetric test with test system aimed at water-soluble $\mathrm{C}$ vitamin definition (Immunodiagnostik AG, Germany), and A, D and $\mathrm{E}$ vitamins content - by immune-enzyme analysis techniques («Human Vitamin A, VA Elisa Kit, 96 CSB», CUSABIO BIOTECH, Co. Ltd., China; «25-OH Vitamin D», «Euroimmun AG» Germany; "Human Vitamin E, VE Elisa Kit, 96 CSB», CUSABIO BIOTECH, Co. Ltd., China). «ELx808IU» immunology lab analyzer and «Infinite F50» immune-enzyme automatic microplate analyzer were used.

All examined children were divided into two groups according to vitamin provision research 
results. Focus group included 74 children with subclinical hypovitaminosis (two and more vitamins deficiency); comparative group was made up of 34 children with vitamin provision being at physiological level. Both groups were comparable in relation to gender characteristics $(\mathrm{d}=0.83)$. In order to accomplish comparative evaluation of primary metabolic processes in children from both groups we examined overall parameters of protein metabolism (crude protein and albumins), carbohydrate metabolism (dextrose), lipid metabolism (crude cholesterol, triglycerides, high and low density lipoproteins), mineral metabolism ( $\mathrm{Fe}$, ionized calcium, $\mathrm{K}, \mathrm{Na}, \mathrm{Mp}$ and $\mathrm{P}$ ), pigmentary metabolism (bilirubin and its fractions, and alkaline phosphatase), and energy metabolism (level of cyclic adenosine monophosphate and cyclic guanosine monophosphate). Simultaneously we paid attention to oxidant and anti-oxidant reactions activity (general anti-oxidant activity of blood serum, lipid hydro peroxides content and malonic dialdehyde content), and children's hormonal profile (adrenaline, noradrenalin, dopamine, hydrocortisone, serotonin, somatotropic and thyrotrophic hormones, and thyroxin). Immune resistance evaluation was based on examining parameters of global blood test and immunogram (phagocytosis, absolute and relative content of $\mathrm{CD}^{+}, \mathrm{CD} 4^{+}, \mathrm{CD} 16^{+} 56^{+}, \mathrm{CD} 19^{+}$, $\mathrm{CD}^{+} 8^{+}, \mathrm{CD}^{+} \mathrm{CD} 5^{+}, \mathrm{CD} 127^{+}-$lymphocytes, and level of A, M, E and G immunoglobulin). All the examinations were completed according to traditional guidelines with the use of «Micros MC-200» microscope, «Konelab» automatic biochemical analyzer, «ELx808» immune and enzyme analyzer, and standard test packs.

Information was analyzed as per variationfrequency analysis with the use of Pirson criterion; numerical value validity was estimated according to Fisher's and Student's tests; and we evaluated "concentration of production induced chemicals in blood - vitamin content in blood" correlation and "vitamin concentration in blood - negative effect marker" correlation according to odds relation calculation (OR) and its confidence interval (DI). $\mathrm{OR} \geq 1$ was the evidence of correlation existence [14].

The results of air quality tests in game rooms of preschool educational establishments showed that formaldehyde content reached $0.0270 \pm 0.0054 \mathrm{mg} / \mathrm{m}^{3}$ and it was higher than hygienic standard $\left(0.01 \mathrm{mg} / \mathrm{m}^{3} ; \mathrm{d} \leq 0.0001\right)$; phenol content amounted to $0.0169 \pm 0.0042 \mathrm{mg} / \mathrm{m}^{3}$ and it was also higher than allowable value $(0.003$ $\left.\mathrm{mg} / \mathrm{m}^{3} ; \mathrm{d} \leq 0.0001\right)$. Simultaneously we found benzene $\left(0.0469 \pm 0.0094 \mathrm{mg} / \mathrm{m}^{3}\right)$ and ethyl benzene $\left(0.0013 \pm 0.0003 \mathrm{mg} / \mathrm{m}^{3}\right)$ in the game rooms air; however their content conformed to hygienic standards $\left(0.1 \mathrm{mg} / \mathrm{m}^{3}\right.$ and $\left.0.02 \mathrm{mg} / \mathrm{m}^{3} ; \mathrm{d}=0.0001\right)$.

Water quality estimation in preschool educational establishments based on Federal Information Fund for Sanitary and Hygienic Monitoring research data and in-situ research results showed that chloroform content in drinking water reached 2.7 maximum allowable concentration; residual chlorine, free and bound, 2.2/1.25 maximum allowable concentration; dichloromethane content was about 8.0 maximum allowable concentration.

As we evaluated vitamin provision in examined children we found out that its average group value $\left(0.228 \pm 0.020 \mathrm{mkg} / \mathrm{cm}^{3}\right)$ did not deviate from physiological standard (0.13-0.51 $\left.\mathrm{mkg} / \mathrm{cm}^{3} ; \mathrm{d}=0.68\right)$; however $15 \%$ of children had vitamin provision not higher than $0.116 \pm 0.006$ мкг $/ \mathrm{cm}^{3}$ and it was authentically lower than the standard $(\mathrm{d} \leq 0.01)$. Average vitamin $\mathrm{E}$ content in blood reached $0.371 \pm 0.033 \mathrm{mkmol} / \mathrm{dm}^{3}$, and individual parameters in all cases corresponded to physiological standard $\left(0.15-0.87 \mathrm{mkmol} / \mathrm{dm}^{3}\right.$, $\mathrm{d}=0.46$ ). At the same time vitamin $\mathrm{C}$ content in the examined children's blood was about only $4.824 \pm 0.314 \mathrm{mg} / \mathrm{cm}^{3}$ that was close to the bottom limit of physiological standard $\left(4.0-14.96 \mathrm{mg} / \mathrm{cm}^{3}\right.$, $\mathrm{d}=0.09$ ); but $75 \%$ of children had much lower level of $\mathrm{C}$ vitamin content - not more than $2.875 \pm 0.229$ $\mathrm{mg} / \mathrm{cm}^{3}(\mathrm{~d} \leq 0.001$ - to the standard). Average vitamin D provision amounted to $29.38 \pm 1.91 \mathrm{ng} / \mathrm{cm}^{3}$ (physiological standard is $30-100 \mathrm{ng} / \mathrm{cm}^{3}, \mathrm{~d}=0.26$ ); however $70 \%$ of children had not more than $23.16 \pm 1.13 \mathrm{ng} / \mathrm{cm}^{3}$ and was lower than physiological standard $(\mathrm{d}=0.02)$. We saw the same trend when investigating vitamin $\mathrm{B}$ content in blood: with average group vitamin $\mathrm{B}_{6}$ content being $6.479 \pm 0.584 \mathrm{mkg} / \mathrm{dm}^{3}$ (physiological standard is $\left.4.6-18.6 \mathrm{mkg} / \mathrm{dm}^{3}, \mathrm{~d}=0.72\right) 60 \%$ of children had this parameter at only $3.459 \pm 0.201 \mathrm{mkg} / \mathrm{dm}^{3}$ and it was lower than the standard $(\mathrm{d}=0.02)$. Average group $\mathrm{B}_{12}$ vitamin content in children's blood amounted to $166.345 \pm 24.494 \mathrm{pmol} / \mathrm{dm}^{3}$ (physiological standard is $\left.149-616 \mathrm{pmol} / \mathrm{dm}^{3}, \mathrm{~d}=0.68\right)$; however $45 \%$ of children had only $121.443 \pm 4.103$ $\mathrm{pmol} / \mathrm{dm}^{3}$, that was lower than the standard $(d=0.02)$.

We accomplished comparative analysis of production induced organic compounds content in blood of children suffering from subclinical hypovitaminosis (focus group) and in blood of children 
with vitamin provision corresponding to physiological standard (comparative group). Research results showed that average chloroform $(0.000813 \pm 0.000073-0.000914 \pm 0.000086$ $\left.\mathrm{mg} / \mathrm{dm}^{3}\right)$ and ethyl benzene $(0.000128 \pm 0.000075-$ $0.000168 \pm 0.000017 \mathrm{mg} / \mathrm{dm}^{3}$ ) content in blood of children from the examined groups authentically exceeded regional background level $(\mathrm{d} \leq 0.001)$; at the same time phenol $(0.0086 \pm 0.0014-$ $\left.0.0075 \pm 0.0016 \quad \mathrm{mg} / \mathrm{dm}^{3}\right), \quad$ formaldehyde $\left(0.00293 \pm 0.00050-0.00217 \pm 0.00026 \mathrm{mg} / \mathrm{dm}^{3}\right)$ and carbon tetrachloride $(0.000033 \pm 0.000005-$
$0.000024 \pm 0.000008 \mathrm{mg} / \mathrm{dm}^{3}$ ) were authentically lower $(\mathrm{d}=0.03-0.001)$ (Table 1). In spite of the fact that average group content of phenol, formaldehyde, chloroform, carbon tetrachloride and ethyl benzene did not have authentic discrepancies in compared groups $(\mathrm{d}=0.18-0.83)$ we determined that the number of children in the focus group with chloroform, carbon tetrachloride and ethyl benzene content exceeding regional background level was 1.4-2.1 times higher than the number of children with the same parameter in the comparative group $(81.1 \%, 37.8 \%$ and $89.2 \%$ correspondingly against $38.2 \%, 20.6 \%$ and $64.7 \%, \mathrm{~d} \leq 0.001)$.

Table 1

Production induced chemical substances content in blood of children with different vitamins $A, C, D, B_{6}$ and $\mathrm{B}_{12}$ provision

\begin{tabular}{|l|c|c|c|c|}
\hline $\begin{array}{l}\text { Chemical } \\
\text { substances }\end{array}$ & $\begin{array}{c}\text { Regional } \\
\text { background } \\
\text { content in } \\
\text { blood }\end{array}$ & Focus group & Comparative group & $\begin{array}{c}\text { Validity of } \\
\text { discrepancy } \\
\text { between groups }\end{array}$ \\
\hline Phenol $\left(\mathrm{mg} / \mathrm{dm}^{3}\right)$ & 0.01 & $0.0086 \pm 0.0014$ & $0.0075 \pm 0.0016$ & 0.61 \\
\hline $\begin{array}{l}\text { Formaldehyde } \\
\left(\mathrm{mg} / \mathrm{dm}^{3}\right)\end{array}$ & 0.005 & $0.00293 \pm 0.00050$ & $0.00217 \pm 0.00026$ & 0.18 \\
\hline $\begin{array}{l}\text { Chloroform } \\
\left(\mathrm{mg} / \mathrm{dm}^{3}\right)\end{array}$ & 0 & $0.000813 \pm 0.000073$ & $0.000914 \pm 0.000086$ & 0.37 \\
\hline $\begin{array}{l}\text { Carbon } \\
\text { tetrachloride } \\
\left(\mathrm{mg} / \mathrm{dm}^{3}\right)\end{array}$ & 0.00086 & $0.000033 \pm 0.000005$ & $0.000024 \pm 0.000008$ & 0.37 \\
\hline $\begin{array}{l}\text { Ethyl benzene } \\
\left(\mathrm{mg} / \mathrm{dm}^{3}\right)\end{array}$ & 0 & $0.000168 \pm 0,000017$ & $0.000128 \pm 0.000075$ & 0.83 \\
\hline
\end{tabular}

Children with polyhypovitaminosis ran relative risk of enhanced concentration in blood in case of such organic compounds as chloroform, carbon tetrachloride and ethyl benzene and this risk was 2.3-6.9 times higher than that in the comparative group (OR=2.31-6.88; $\mathrm{DI}=1.21-8.44$; $\mathrm{d}=0.02-0.04)$. Then, as we accomplished regression analysis we determined weak correlation between enhanced chloroform and carbon tetrachloride concentration in blood and vitamin A lower level $(\mathrm{F}=16.59$ $\left.216.88, R^{2}=0.19-0.26, d=0.02-0.04\right)$; moderate correlation between carbon tetrachloride enhanced concentration with lower levels of vitamins B6 and $\mathrm{C}\left(\mathrm{F}=28.77-381.16, \mathrm{R}^{2}=0.39-0.48, \mathrm{~d}=0.001-0.002\right)$. We should note that a number of children in the focus group with phenol and formaldehyde content in blood exceeding regional background content was 1.6-1.8 times higher than the number of children having the same parameter in the comparative group $(31.1 \%$ and $18.9 \%$ correspondingly against $17.7 \%$ and $11.8 \%, \mathrm{~d}=0.001)$. Enhanced concentra- tions of phenol and formaldehyde were likely to be found in children with polyhypovitaminosis, relative risk of their formation was 1.8-2.1 times higher than for children from the comparative group $(\mathrm{OR}=1.77-2.11 ; \mathrm{DI}=1.33-4.07 ; \mathrm{d}=0.03-0.05)$. We detected moderate correlation between phenol and formaldehyde enhanced content and vitamin A lower level $\left(\mathrm{F}=12.03-78.18, \mathrm{R}^{2}=0.39-0.46, \mathrm{~d}=0.01\right.$ 0.02) and vitamin $C$ lower level $(F=44.31-109.53$, $\mathrm{R}^{2}=0.37-0.44, \mathrm{~d}=0.01-0.02$ ).

Comparative analysis of average group hematologic parameters in both children' groups proved there were no substantial deviations from physiological standard for the majority of them (table 2). The only exceptions included eosinophilic and lymphocytic index and relative lymphocytes content. Eosinophilic and lymphocytic index level exceeded physiological standard $(0.015 \pm 0.020$ a.u. $)$ in both groups; it was $0.064 \pm 0.006$ a.u. in the focus group and $0.070 \pm 0.007$ a.u. in the comparative group 
( $d=0.03-0.04)$. As for lymphocytes relative content their level reached $45.62 \pm 3.47 \%$ in the focus group and $49.71 \pm 3.31 \%$ in the comparative group ( $\mathrm{d}=0.03-0.04$ with regard to physiological standard of $36-40 \%$ ). At the same time contrastive research of hematological parameters in both children's groups allowed us to define a number of differences. Children in comparative group had authentically lower level of erythrocytes absolute content $\left(4.01 \pm 0.17 \times 10^{9} / \mathrm{dm}^{3}\right.$ against $4.51 \pm 0.14 \times 10^{9} / \mathrm{dm}^{3}$, $\mathrm{d}=0.01$ ) and higher level of reticulocytes
$(0.477 \pm 0.0060 \%$ against $0.361 \pm 0.060 \%, \mathrm{~d}=0.01)$; but children in the focus group had higher level of leucocytes and segmented neutrophils content $\left(7.63 \pm 0.27 \times 10^{9} / \mathrm{dm}^{3}\right.$ against $5.29 \pm 0,50 \times 10^{9} / \mathrm{dm}^{3}$ and $45.54 \pm 7.93 \%$ against $37.77 \pm 3.54 \%$ correspondingly; $\mathrm{d}=0.01$ ), and lower level of lymphocytes content $(40.62 \pm 7.47 \%$ against $49.71 \pm 3.31 \%)$ and monocytes content $(5.05 \pm 0.88 \%$ against $6.83 \pm 0.61 \%)$ than children in the comparative group $(\mathrm{d}=0.04)$ (table 2$)$.

Table 2

Comparative analysis of hematological parameters in children with different provision of $\mathrm{A}, \mathrm{C}, \mathrm{D}, \mathrm{B}_{6}$ and $\mathrm{B}_{12}$ vitamins

\begin{tabular}{|c|c|c|c|c|}
\hline Parameter & $\begin{array}{l}\text { Physiological } \\
\text { standard }\end{array}$ & Focus group & $\begin{array}{l}\text { Comparative } \\
\text { group }\end{array}$ & $\begin{array}{l}\text { Validity of dis- } \\
\text { crepancy between } \\
\text { groups }\end{array}$ \\
\hline Hemoglobin, gr/dm ${ }^{3}$ & $115-135$ & $126.69 \pm 4.05$ & $126.41 \pm 2.91$ & 0.91 \\
\hline $\begin{array}{l}\text { Erythrocytes, } \\
10^{12} / \mathrm{dm}^{3}\end{array}$ & $3.9-5.3$ & $4,01 \pm 0.17$ & $4.51 \pm 0.14$ & 0.01 \\
\hline $\begin{array}{l}\text { Blood color index, } \\
\text { picograms }\end{array}$ & $24-30$ & $28.39 \pm 0.94$ & $27.94 \pm 0.92$ & 0.47 \\
\hline $\begin{array}{l}\text { Leucocytes, } \\
10^{9} / \mathrm{dm}^{3}\end{array}$ & $5.5-7$ & $7.63 \pm 0.27$ & $5.29 \pm 0.50$ & 0.001 \\
\hline $\begin{array}{l}\text { Eosinophils abso- } \\
\text { lute number, } \\
10^{9} / \mathrm{dm}^{3}\end{array}$ & $150-350$ & $255.69 \pm 76.59$ & $240.41 \pm 67.28$ & 0.45 \\
\hline Stab neutrophils, \% & $0-3$ & $1.15 \pm 0.11$ & $1.00 \pm 0.00$ & 0.15 \\
\hline $\begin{array}{l}\text { Segmented neutro- } \\
\text { phils, \% }\end{array}$ & $37-41$ & $45.54 \pm 7.93$ & $37.77 \pm 3.54$ & 0.01 \\
\hline Lymphocytes, \% & $36-40$ & $45.62 \pm 3.47$ & $49.71 \pm 3.31$ & 0.04 \\
\hline Monocytes, $\%$ & $5-6$ & $5.05 \pm 0.38$ & $6.83 \pm 0.61$ & 0.04 \\
\hline $\begin{array}{l}\text { Eosinophilic lym- } \\
\text { phocytic index, a.u. }\end{array}$ & $0.015-0.02$ & $0.064 \pm 0.006$ & $0.070 \pm 0.007$ & 0.71 \\
\hline Reticulocytes, \% & $0.2-0.7$ & $0.477 \pm 0.060$ & $0.361 \pm 0.060$ & 0.01 \\
\hline $\begin{array}{l}\text { Blood plates, } \\
10^{9} / \mathrm{дm}^{3}\end{array}$ & $180-320$ & $306.06 \pm 11.37$ & $314.23 \pm 21.59$ & 0.74 \\
\hline
\end{tabular}

Comparative evaluation of basic metabolism processes in both groups proved that there were no authentic discrepancies between physiological standard and average group parameters of protein, carbohydrate, lipid, mineral, and energy metabolism and antioxidant protection (table 3 ). Still children in the focus group had lower level of crude protein $\left(65.37 \pm 1.91 \mathrm{gr} / \mathrm{dm}^{3}\right)$ than children in the comparative group $\left(71.00 \pm 2.14 \mathrm{gr} / \mathrm{dm}^{3}, \mathrm{~d}=0.01\right)$, combined with lower level of dextrose $(4.01 \pm 0.27$ $\mathrm{mmol} / \mathrm{dm}^{3}$ against $4.69 \pm 0.34 \mathrm{mmol} / \mathrm{dm}^{3}, \mathrm{~d}=0.02$ ). Besides we determined discrepancies in mineral metabolism parameters; thus, $\mathrm{K}$ content in blood of children in the focus group amounted to $3.85 \pm 0.12$ $\mathrm{mmol} / \mathrm{dm}^{3}$ (against $4.46 \pm 0.14 \mathrm{mmol} / \mathrm{dm}^{3}$ in the comparative group, $\mathrm{d}=0.006) ; \mathrm{Na} / \mathrm{K}$ coefficient was $34.92 \pm 0.46$ (against $32.00 \pm 0.39 \mathrm{mmol} / \mathrm{dm}^{3}$, $\mathrm{p}=0.0003)$, Fe level was $12.14 \pm 3.31 \mathrm{mmol} / \mathrm{dm}^{3}$ (against $17.17 \pm 3.29 \mathrm{mmol} / \mathrm{dm}^{3}, \mathrm{~d}=0.0001$ ). Lipid metabolism research enabled us to define authentically higher levels of crude cholesterol $(4.78 \pm 0.34$ $\mathrm{mkmol} / \mathrm{dm}^{3}$ ) and low density lyposaccharides $\left(2.79 \pm 0.38 \mathrm{mkmol} / \mathrm{dm}^{3}\right)$ in the focus group than in the comparative group $\left(4.08 \pm 0.27 \mathrm{mkmol} / \mathrm{dm}^{3}\right.$ and $2.12 \pm 0.26 \mathrm{mkmol} / \mathrm{dm}^{3}$ correspondingly, $\mathrm{d}=0.005$ $0.02)$. 
Table 3

Comparative analysis of biochemical parameters in children with different $A, C, D, B_{6}$ и $B_{12}$ vitamin provision

\begin{tabular}{|c|c|c|c|c|}
\hline Parameter & $\begin{array}{l}\text { Physiological } \\
\text { standard }\end{array}$ & Focus group & $\begin{array}{l}\text { Comparative } \\
\text { group }\end{array}$ & $\begin{array}{c}\text { Validity of } \\
\text { discrepancy } \\
\text { between group } \\
(\mathrm{d} \leq 0.05)\end{array}$ \\
\hline $\begin{array}{l}\text { Glutamic-pyruvic } \\
\text { transaminase, E/dm }\end{array}$ & $5-42$ & $16.92 \pm 1.75$ & $16.88 \pm 2.12$ & 0.941 \\
\hline $\begin{array}{l}\text { Aspartate } \\
\text { aminotransferase, E/dm }\end{array}$ & $6-37$ & $35.39 \pm 5.01$ & $33.94 \pm 2.19$ & 0.121 \\
\hline Albumins, $\mathrm{gr} / \mathrm{dm}^{3}$ & $35-50$ & $44.00 \pm 1.41$ & $43.53 \pm 1.41$ & 0.182 \\
\hline $\begin{array}{l}\text { Crude bilirubin, } \\
\mathrm{mkmol} / \mathrm{dm}^{3}\end{array}$ & $0-18.8$ & $8.07 \pm 1.92$ & $8.38 \pm 2,20$ & 0.563 \\
\hline $\begin{array}{l}\text { Conjugated bilirubin, } \\
\mathrm{mkmol} / \mathrm{dm}^{3}\end{array}$ & $0-4.3$ & $1.85 \pm 0.45$ & $1.78 \pm 0.27$ & 0.441 \\
\hline Dextrose, $\mathrm{mmol} / \mathrm{dm}^{3}$ & $3.33-5.55$ & $4.01 \pm 0.27$ & $4.69 \pm 0.34$ & 0.002 \\
\hline $\mathrm{Fe}, \mathrm{mkmol} / \mathrm{dm}^{3}$ & $6.6-28$ & $12.14 \pm 3.31$ & $17.77 \pm 3.29$ & 0.0001 \\
\hline $\mathrm{K}, \mathrm{mmol} / \mathrm{dm}^{3}$ & $3.6-5.5$ & $3.85 \pm 0.12$ & $4.46 \pm 0.14$ & 0.006 \\
\hline $\mathrm{Na}, \mathrm{mmol} / \mathrm{dm}^{3}$ & $135-147$ & $136.33 \pm 1.31$ & $136.20 \pm 1.21$ & 0.67 \\
\hline $\mathrm{Na} / \mathrm{K}$ coefficient & $30-50$ & $34.92 \pm 0.46$ & $32.00 \pm 0.39$ & 0.003 \\
\hline Creatinine, $\mathrm{mkmol} / \mathrm{dm}^{3}$ & $28-88$ & $49.31 \pm 2.19$ & $56.06 \pm 3.36$ & 0.041 \\
\hline Crude protein, $\mathrm{gr} / \mathrm{dm}^{3}$ & $60-80$ & $65.37 \pm 1.91$ & $71.00 \pm 1.14$ & 0.001 \\
\hline Triglycerides, $\mathrm{mmol} / \mathrm{dm}^{3}$ & $0.3-1.7$ & $0.52 \pm 0.13$ & $0.54 \pm 0.09$ & 0.38 \\
\hline $\begin{array}{l}\text { High density lypoproteins } \\
\text { cholesterol, } \mathrm{mmol} / \mathrm{dm}^{3}\end{array}$ & $0.8-2.2$ & $1.35 \pm 0.15$ & $1.32 \pm 0.08$ & 0.22 \\
\hline $\begin{array}{l}\text { Low density lypoproteins } \\
\text { cholesterol, } \mathrm{mmol} / \mathrm{dm}^{3}\end{array}$ & $1.55-3.9$ & $2.79 \pm 0.38$ & $2.12 \pm 0.26$ & 0.005 \\
\hline $\begin{array}{l}\text { Crude cholesterol, } \\
\mathrm{mmol} / \mathrm{dm}^{3}\end{array}$ & $3.11-5.44$ & $4.78 \pm 0.34$ & $4.08 \pm 0.27$ & 0.02 \\
\hline $\begin{array}{l}\text { Alkaline phosphatase, } \\
\text { E/dm }\end{array}$ & $71-645$ & $234.29 \pm 25.33$ & $310.33 \pm 31.07$ & 0.001 \\
\hline $\begin{array}{l}\text { Malonic plasma } \\
\text { dealdehyde, } \mathrm{mkmol} / \mathrm{cm}^{3}\end{array}$ & $1.8-2.5$ & $2.22 \pm 0.19$ & $2.26 \pm 0.16$ & 0.36 \\
\hline $\begin{array}{l}\text { Lipid hydroperoxides, } \\
\mathrm{mkmol} / \mathrm{dm}^{3}\end{array}$ & $0-350$ & $311.36 \pm 102.84$ & $325.74 \pm 96.49$ & 0.536 \\
\hline $\begin{array}{l}\text { Glutathione peroxidase in } \\
\text { blood serum, } \mathrm{ngr} / \mathrm{cm}^{3}\end{array}$ & $27.5-54.70$ & $34.44 \pm 5.29$ & $43.78 \pm 5.61$ & 0.001 \\
\hline $\begin{array}{l}\text { Superoxide dismutase, } \\
\mathrm{ngr} / \mathrm{cm}^{3}\end{array}$ & $45.9-98.3$ & $44.21 \pm 5.00$ & $59.39 \pm 7.00$ & 0.014 \\
\hline $\begin{array}{l}\text { Cyclic adenosine } \\
\text { monophosphate, } \mathrm{pmol} / \mathrm{cm}^{3}\end{array}$ & $5.9-10.9$ & $6.36 \pm 0.41$ & $6.33 \pm 0.36$ & 0.71 \\
\hline $\begin{array}{l}\text { Cyclic guanosine } \\
\text { monophosphate, } \mathrm{pmol} / \mathrm{cm}^{3}\end{array}$ & $1.5-5.4$ & $2.76 \pm 0.84$ & $4.005 \pm 0.35$ & 0.032 \\
\hline $\begin{array}{l}\text { Blood serum antioxidant } \\
\text { activity, } \%\end{array}$ & $36.2-38.6$ & $35.23 \pm 1.33$ & $38.63 \pm 1.04$ & 0.01 \\
\hline
\end{tabular}

Children in the focus group had lower levels of creatinine $\left(49.31 \pm 2.19 \mathrm{mkmol} / \mathrm{dm}^{3}\right)$ and alkaline phosphatase $\left(234.29 \pm 25.33 \mathrm{mkmol} / \mathrm{dm}^{3}\right)$ than those in the comparative group $(56.06 \pm 3.36$ $\mathrm{mkmol} / \mathrm{dm}^{3}$ and $310.33 \pm 31.07 \mathrm{mkmol} / \mathrm{dm}^{3}$ correspondingly, $\mathrm{d}=0.0001-0.041)$. Having examined 70 oxidant and antioxidant processes we found out that antioxidant protection in the focus group (glutathione peroxidase $34.44 \pm 5.29 \mathrm{ng} / \mathrm{cm}^{3}$ and superoxide dismutase $44.21 \pm 5.00 \mathrm{ng} / \mathrm{cm}^{3}$ ) was authentically lower than in the comparative group (glutathione peroxidase $43.78 \pm 5.61 \mathrm{ng} / \mathrm{cm}^{3}$ and 
superoxide dismutase $59.39 \pm 7.00 \quad \mathrm{ng} / \mathrm{cm}^{3}$, $\mathrm{d}=0.0001-0.0014$ ) (table 3). Besides, blood serum antioxidant activity in the focus group amounted to $35.23 \pm 1.33 \%$, while in the comparative group this parameter was higher and reached $38.63 \pm 1.04 \%$ $(d=0.01)$. Energy metabolism research showed authentically lower level of cyclic guanosine monophosphate in the focus group than in the compara-

tive group $\left(2.76 \pm 0.84 \mathrm{pmol} / \mathrm{cm}^{3}\right.$ against $4.05 \pm 0.35$ $\mathrm{pmol} / \mathrm{cm}^{3}, \mathrm{p}=0.032$ ) (table 3). Immunologic parameters research showed that all examined children had T-and B-lymphocytes subpopulation content and $\mathrm{G}$ category immunoglobulins contents equal to physiological standard $(\mathrm{d}=0,10-0,90)$ (table 4).

Table 4

Comparative analysis of immunologic parameters in children with different $\mathrm{A}, \mathrm{C}, \mathrm{D}, \mathrm{B}_{6}$ and $\mathrm{B}_{12}$ vitamin provision

\begin{tabular}{|c|c|c|c|c|}
\hline Parameter & $\begin{array}{l}\text { Physiolog } \\
\text { ical } \\
\text { standard }\end{array}$ & Focus group & Comparative group & $\begin{array}{l}\text { Valid } \\
\text { ity of } \\
\text { discrepancy } \\
\text { between } \\
\text { groups } \\
(\mathrm{d} \leq 0, \\
05)\end{array}$ \\
\hline Leucocutes, $10^{9} / \mathrm{dm}^{3}$ & $5.0-9.0$ & $7.43 \pm 0.38$ & $6.47 \pm 0.23$ & 0.02 \\
\hline Lymphocytes, \% & $35-55$ & $45.50 \pm 4.95$ & $46.89 \pm 6.33$ & 0.58 \\
\hline CD16+56+lymphocytes, relative, $\%$ & $5-27$ & $6.21 \pm 2.06$ & $10.67 \pm 2.80$ & 0.023 \\
\hline CD19+-lymphocytes, absolute, $10^{9} /$ дм $^{3}$ & $0.09-0.66$ & $0.25 \pm 0.14$ & $0.62 \pm 0.25$ & 0.01 \\
\hline CD19+-lymhpocytes, relative, $\%$ & $6-25$ & $11.01 \pm 2.21$ & $17.61 \pm 3.17$ & 0.02 \\
\hline CD3+-lymphocytes, absolute, $10^{9} / \mathrm{dm}^{3}$ & $0.69-2.54$ & $2.43 \pm 1.58$ & $2.56 \pm 1.47$ & 0.23 \\
\hline CD3+-lymphocytes, relative, $\%$ & $55-84$ & $71.33 \pm 5.17$ & $76.51 \pm 6.35$ & 0.02 \\
\hline CD3+CD25+lymphocytes, relative, $\%$ & $5-12$ & $3.00 \pm 0.13$ & $4.43 \pm 0.48$ & 0.04 \\
\hline $\begin{array}{l}\text { CD3+CD4+lymphocytes, absolute, } \\
10^{9} / \mathrm{dm}^{3}\end{array}$ & $0.41-1.59$ & $0.98 \pm 0.15$ & $1.63 \pm 0.02$ & 0.04 \\
\hline CD3+CD8+lymhpcytes, absolute, $10^{9} / \mathrm{dm}^{3}$ & $0.19-1.14$ & $1.14 \pm 0.31$ & $1.01 \pm 0.49$ & 0.42 \\
\hline CD3+CD8+lymphocytes, relative, $\%$ & $13-41$ & $28.00 \pm 5.41$ & $27.33 \pm 9.41$ & 0.47 \\
\hline $\begin{array}{l}\text { CD3+CD95+lymphocytes, absolute, } \\
10^{9} / \mathrm{dm}^{3}\end{array}$ & $0.4-0.7$ & $0.31 \pm 0.12$ & $0.32 \pm 0.11$ & 0.42 \\
\hline CD3+CD95+lymphocytes, relative, $\%$ & $15-25$ & $9.01 \pm 1.11$ & $8.67 \pm 2.87$ & 0.52 \\
\hline CD127+- lymphocytes, relative, $\%$ & & $1.28 \pm 0.35$ & $2.72 \pm 0.73$ & 0.001 \\
\hline CD127+- lymphocytes, absolute, $10^{9} / \mathrm{dm}^{3}$ & & $0.05 \pm 0.01$ & $0.11 \pm 0.03$ & 0.01 \\
\hline $\mathrm{IgG}, \mathrm{gr} / \mathrm{dm}^{3}$ & $\begin{array}{l}9.13- \\
10.75\end{array}$ & $8.75 \pm 0.75$ & $9.46 \pm 1.37$ & 0.22 \\
\hline $\mathrm{IgM}, \mathrm{gr} / \mathrm{dm}^{3}$ & $1.4-1.82$ & $1.11 \pm 0.12$ & $1.59 \pm 0.12$ & 0.04 \\
\hline $\mathrm{IgA}, \mathrm{gr} / \mathrm{dm}^{3}$ & $0.98-1.12$ & $1.05 \pm 0.08$ & $1.23 \pm 0.04$ & 0.04 \\
\hline IgE crude, $\mathrm{ME} / \mathrm{cm}^{3}$ & $0-49.9$ & $\begin{array}{l}74.46 \pm 11.2 \\
6\end{array}$ & $\begin{array}{r}22.79 \pm 13.3 \\
4\end{array}$ & 0.001 \\
\hline Absolute phagocytosis, $10^{9} / \mathrm{dm}^{3}$ & $\begin{array}{l}0.964- \\
2.988\end{array}$ & $2.13 \pm 1.01$ & $1.44 \pm 0.32$ & 0.03 \\
\hline
\end{tabular}

At the same time children in the focus group had higher level of leucocytes $\left(7.23 \pm 0.38 \times 10^{9} / \mathrm{dm}^{3}\right)$ than children in the comparative group $\left(6.47 \pm 0.63 \times 10^{9} / \mathrm{dm}^{3}, \mathrm{p}=0.002\right)$; absolute phagocytosis in the focus group amounted to $2.13 \pm 1.01 \times 10^{9} / \mathrm{dm}^{3}$ which was 1.5 times higher than the same parameter in the comparative group $(\mathrm{p}=0.0001)$. Still absolute content of CD3+CD4+and CD19+ lymphocytes, as well as relative content of $\mathrm{CD} 3+\mathrm{CD} 25+-, \quad \mathrm{CD} 3+-, \quad \mathrm{CD} 19+-$
CD16+CD56+ and CD3+CD25+ lymphocytes was authentically lower in the focus group than in the comparative group $(\mathrm{d}=0,0001-0,04)$, and it proves proliferative processes of immunocompetent cells to be less active. We should note that Blymphocytic component of immune reaction was also less active in children with subclinical vitamin provision and it is confirmed by lower concentrations of $\mathrm{A}$ and $\mathrm{M}$ category immunoglobulins. However, E immunoglobulin level in the fo- 
cus group amounted to $74.46 \pm 11.26 \mathrm{ME} / \mathrm{cm}^{3}$ and it was 3.5 times higher than in the comparative group $\left(22.79 \pm 13.34 \mathrm{ME} / \mathrm{cm}^{3}, \mathrm{~d}=0.0001\right)$, which is a sign of more active allergic response reaction (table 4).

Hormonal profile research showed that hormones content corresponded to physiological standard in both groups $(\mathrm{d}=0.24-0.67)$. But as we carried out comparative analysis we found out that children in the focus group had authentically higher levels of adrenaline $\left(49.41 \pm 11.13 \mathrm{pg} / \mathrm{cm}^{3}\right)$, dopamine $\left(41.91 \pm 5.16 \quad \mathrm{pg} / \mathrm{cm}^{3}\right), \quad$ hydrcortisone $\left(383.34 \pm 142.37 \mathrm{nmol} / \mathrm{cm}^{3}\right)$, noradrenaline $\left(327.30 \pm 16.38 \mathrm{pg} / \mathrm{cm}^{3}\right)$ and thyrotrophic hormone $\left(3.37 \pm 0.26 \mathrm{mcME} / \mathrm{cm}^{3}\right)$ than children in the comparative group $\left(33.10 \pm 6.15 \mathrm{pg} / \mathrm{cm}^{3}, 23.76 \pm 6.65\right.$ $\mathrm{pg} / \mathrm{cm}^{3}, 237.43 \pm 49.07 \mathrm{nmol} / \mathrm{cm}^{3}, 284.31 \pm 26.35$ $\mathrm{pg} / \mathrm{cm}^{3}$ and $2.38 \pm 0.65 \mathrm{mcME} / \mathrm{cm}^{3}$ correspondingly) $\quad(\mathrm{d}=0.0006-0.01) \quad($ table 5$)$.

Comparative analysis of hormonal profile

Table 5 in children with different $\mathrm{A}, \mathrm{C}, \mathrm{D}, \mathrm{B}_{6}$ and $\mathrm{B}_{12}$ vitamin provision

\begin{tabular}{|c|c|c|c|c|}
\hline Parameter & $\begin{array}{l}\text { Physiological } \\
\text { standard }\end{array}$ & Focus group & $\begin{array}{l}\text { Comparative } \\
\text { group }\end{array}$ & $\begin{array}{c}\text { Validity of } \\
\text { discrepancy } \\
\text { between groups } \\
(\mathrm{p} \leq 0.05)\end{array}$ \\
\hline Adrenaline, $\mathrm{pg} / \mathrm{cm}^{3}$ & $0-100$ & $49.41 \pm 11.13$ & $33.10 \pm 6.15$ & 0.0006 \\
\hline Dopamine, $\mathrm{pg} / \mathrm{cm}^{3}$ & $0-100$ & $41.91 \pm 5.16$ & $23.76 \pm 6.65$ & 0.001 \\
\hline $\begin{array}{l}\text { Hydrocortisone, } \\
\mathrm{nmol} / \mathrm{cm}^{3}\end{array}$ & $140-600$ & $383.34 \pm 142.37$ & $237.43 \pm 49.07$ & 0.0007 \\
\hline $\begin{array}{l}\text { Noradrenaline, } \\
\mathrm{pg} / \mathrm{cm}^{3}\end{array}$ & $0-600$ & $327.30 \pm 16.38$ & $284.31 \pm 26.35$ & 0.0012 \\
\hline Serotonin, $\mathrm{ngr} / \mathrm{cm}^{3}$ & $80-450$ & $170.70 \pm 74.97$ & $191.24 \pm 100.82$ & 0.21 \\
\hline $\begin{array}{l}\text { Triiodothyronine, } \\
\mathrm{ngr} / \mathrm{cm}^{3}\end{array}$ & $0.6-2.1$ & $2.31 \pm 0.06$ & $2.12 \pm 0.43$ & 0.08 \\
\hline $\begin{array}{l}\text { Crude thyroxine } \\
\text { (immune enzyme } \\
\text { blood analysis), } \\
\text { nmol/ } \mathrm{dm}^{3}\end{array}$ & $83-170$ & $93.15 \pm 6.38$ & $117.62 \pm 9,55$ & 0.01 \\
\hline $\begin{array}{l}\text { Free thyroxine, } \\
\mathrm{nmol} / \mathrm{dm}^{3}\end{array}$ & $10-25$ & $15.02 \pm 2.43$ & $13.45 \pm 1.12$ & 0.1 \\
\hline $\begin{array}{l}\text { Thyrotropic } \\
\text { hormone, } \\
\mathrm{mcME} / \mathrm{cm}^{3}\end{array}$ & $0.3-4$ & $3.37 \pm 0.26$ & $2.38 \pm 0.65$ & 0.014 \\
\hline $\begin{array}{l}\text { Somatotropic } \\
\text { hormone, } \\
\mathrm{mME} / \mathrm{dm}^{3}\end{array}$ & $2-20$ & $5.17 \pm 1.37$ & $3.37 \pm 1.76$ & 0.12 \\
\hline
\end{tabular}

Conclusions. Research results showed that children suffering from subclinical polyhypovitaminosis and being under combined (inhalant and per os) effect of phenol, formaldehyde, aromatic hydrocarbons and chlorine and organic compounds run 1.46.9 times higher risk to have higher organic compounds concentration in blood than children with vitamin provision equal to physiological standard. Even subclinical polyhypovitaminosis combined with higher organic compounds concentration in blood lead to $15-20 \%$ higher erythrogenesis ten- sion, 1.2-1.4 lower proliferative activity of lymphomonocitic germ and non-specific resistance parameters, protein and carbohydrate metabolism deceleration. Such children have lower level of enzymes (alkaline phosphatase and creatinine), antioxidant protection parameters and cyclic guanosine monophosphate and it indirectly proves synthesis processes deceleration, antioxidant protection reserves exhaustion and energy metabolism deficiency. We should pay special attention to negative trends in lipid metabolism (higher levels of crude cholesterol 
and lower density lyposaccharides) combined with tenser hormonal regulation reactions. If such trends persist it can result in earlier evolvement of cardiovascular pathology at elder ages.
The obtained results call for creation of specialized programs aimed at dietary intake vitaminization for children living in poor sanitary and hygienic conditions.

\section{References}

1. Gromova O.A., Namazova L.S. Vitaminy i mineraly v sovremennoj klinicheskoj medicine: vozmozhnosti lechebnyh i profilakticheskih tehnologij [Vitamins and minerals in modern clinical medicine: possibilities of therapeutic and preventive technologies]. Moscow, 2003, 56 p. (in Russian).

2. Gromova O.A. Diagnostika, lechenie i profilaktika deficita vitamina D (po materialam klinicheskih rekomendacij Amerikanskogo obshhestva jendokrinologov) [Diagnosis, treatment and prevention of vitamin D deficiency (based on the recommendations of the American Society of Clinical Endocrinologists)]. Osteoporoz i osteopatii, 2012, no. 1, pp. 34-37. (in Russian).

3. Gromova O.A. Receptura vitaminnyh kompleksov, vospolnjajushhih fiziologicheskie potrebnosti $\mathrm{v}$ vitaminah u detej [Formulation of vitamin complexes, supplying physiological needs in vitamins in children]. Voprosy sovremennoj pediatrii, 2009, Vol. 8, no. 6, pp. 77-84. (in Russian).

4. Zaitseva N.V., May I.V., Kleyn S.V. K voprosu ustanovlenija i dokazatel'stva vreda zdorov'ju naselenija pri vyjavlenii nepriemlemogo riska, obuslovlennogo faktorami sredy obitanija [On the determination and proof of damage to human health due to an unacceptable health risk caused by environmental factors]. Analiz riska zdorov'ju, 2013, no. 2, pp. 14-26. (in Russian).

5. Kon' I.Ja. Deficit vitaminov u detej: osnovnye prichiny, formy i puti proffilaktiki u detej rannego i doshkol' $\neg$ nogo vozrasta [Deficiency of vitamins in children: the main causes, forms and ways precautions in infants and children of preschool age]. Voprosy sovremennoj pediatrii, 2002, Vol. 1., no. 2, pp. 62-66. (in Russian).

6. Kon' I.Ja. Racional'noe pitanie v sohranenii zdorov'ja [Rational nutrition in maintaining health]. In A.A. Baranova, L.A. Shhepljaginoj, ed. Fiziologija rosta i razvitija detej i podrostkov, Moscow, 2000, pp. 515-545. (in Russian).

7. Kostantin Zh., Kugach V.V. Vitaminy i ih rol' v organizme [Vitamins and their role in the organism]. Vestnik farmacii, 2006, no. 2 (32), pp. 58-70. (in Russian).

8. Kudrin A.V., Gromova O.A. Mikrojelementy v immunologii i onkologii [Microelements in immunology and oncology]. Moscow: GJeOTAR-Media, 2007, 544 p. (in Russian).

9. Kuchma V.R. Gigiena detej i podrostkov [Hygiene of children and adolescents]. Moscow: GJeOTAR-Media, 2008, 476 p. (in Russian).

10. Ladodo K.S. Rasprostranennost' deficita mineralov i vitaminov u detej vtorogo goda zhizni [Prevalence of mineral and vitamin deficiencies in infants during the second year of life]. Rossijskij vestnik perinatologii i pediatrii, 2011, Vol. 56, no. 5, pp. 94-98. (in Russian).

11. Tutel'jan V.A., Razumov A.N., Vjalkov A.I., Mihajlov V.I., Moskalenko K.A., Odinec A.G., Sbezhneva V.G., Sergeev V.N. Nauchnye osnovy zdorovogo pitanija [Scientific fundamentals of healthy eating]. Moscow: Izdatel'skij dom «Panorama», 2010, 816 p. (in Russian).

12. Chesnokova L.A., Kuz'micheva N.A., Krasikov S.I., Sharapova N.V., Mihajlova I.V. Nekotorye pokazateli vitaminnogo i antioksidantnogo statusa u zhitelej regiona [Some indicators of vitamin and antioxidatic status of inhabitans of region]. Zdorov'e naselenija i sreda obitanija, 2013, no. 6 (243), pp. 911. (in Russian).

13. Kodencova V.M., Vrzhesinskaja O.A., Spirichev V.B., Shatnjuk L.N. Obogashhenie raciona detej vitaminami vzamen S-vitaminizacii [Enrichment of the diet of children with vitamins instead of Cfortification]. Pediatrija, 2010, Vol. 1, no. 1, pp. 42-43. (in Russian).

14. Rebrov V.G., Gromova O.A. Vitaminy, makro- i mikrojelementy [Vitamins, macro- and microelements]. Moscow: Gojetar-media, 2008, 954 p. (in Russian). 